\title{
The Impact of Operational Performance on Profitability: An ARDL Approach on Turkish Airlines
}

\section{Operasyonel Performansın Karlılı̆̆a Etkisi: Türk Hava Yolları Üzerine ARDL Yaklaşımı}

\author{
Dr. Öğr. Üyesi Eyup ATİOĞLU(iD 1
}

\begin{abstract}
In this study, the effect of revenue passenger kilometer, passenger load factor and number of revenue passengers, which are among the commonly used operational performance indicators, on the return on equity was examined by ARDL model specifically for Turkish Airlines. The data set includes 40 observations on a quarterly basis between 2010 and 2019. The study suggests that the passenger load factor has a significant effect on the return on equity. It has been revealed that the revenue passenger kilometer has a low negative effect on the return on equity, and number of revenue passenger has a low positive effect on the return on equity. Empirical results show that when the increase in the number of revenue passenger is not supported by passenger load factor, in other words, because of the flights where the breakeven point is not exceeded in terms of cost, it is evaluated that revenue passenger kilometer and the number of revenue passenger do not affect the return on equity positively.
\end{abstract}

Keywords: Return on equity (ROE), operational performance, ARDL approach

Paper Type: Research

\section{Öz}

$\mathrm{Bu}$ çalışmada yaygın olarak kullanılan operasyonel performans göstergelerinden ücretli yolcu kilometre, yolcu doluluk oranı ve ücretli yolcu sayısının özsermaye karlılığına etkisi Türk Hava Yolları'na yönelik olarak ARDL modeli ile incelenmiştir. Veri seti, 2010 ile 2019 yılları arasında üç aylık bazda 40 gözlem içermektedir. Çalışma, yolcu doluluk oranının özsermaye karlılığı üzerinde önemli bir etkiye sahip olduğunu göstermektedir. Ücretli yolcu kilometrenin özsermaye karlılığı üzerinde düşük olumsuz etkiye sahip olduğu, ücretli yolcu sayısının ise özsermaye karlılığ üzerinde düşük olumlu etkiye sahip olduğu ortaya çıkmıştır. Ampirik sonuçlar, ücretli yolcu sayısındaki artışın yolcu doluluk oranı ile desteklenmediğinde, bir başka deyişle maliyet açısından başabaş noktasının aşılmadığı uçuşlar nedeniyle, ücretli yolcu kilometre ve ücretli yolcu sayısının özsermaye karlılığını olumlu etkilemediğini göstermektedir.

Anahtar Kelimeler: Özsermaye karlılı̆̆ı, operasyonel performans, ARDL yaklaşımı

Makale Türü: Araştırma

\section{Introduction}

The ultimate aim of airlines in financial management is to maximize the market value of the business and the earnings of the shareholders. One of the most important tools in achieving this ultimate goal is to gain and increase profits. Airlines are trying to achieve their goals through their operational performance. In this context, it is important to examine the effects of managerial decisions that will shape the operational performance of airline companies on profitability (İskenderoğlu, Karadeniz, \& Atioğlu, 2012, s. 291).

${ }^{1}$ Kapadokya Üniversitesi, Uygulamalı Bilimler Yüksekokulu, eyup.atioglu@kapadokya.edu.tr

Atıf için (to cite): Atioğlu, E. (2021). The impact of operational performance on profitability: An ARDL approach on Turkish Airlines. Afyon Kocatepe Üniversitesi Sosyal Bilimler Dergisi, 23(4), 1441-1452. 
Profit can be explained as the positive difference between the total revenues obtained as a result of the activities performed in a certain period and the total costs incurred for the activities (Türkiş, 2001, s. 65). Profitability, on the other hand, is a concept that shows the operating results of businesses as a ratio rather than an amount. In other words, it gives information about whether the profit earned by the enterprise is measured, sufficient and satisfactory on the assets, equity and net sales used in the production (Apak \& Demirel, 2010, s. 165). There are various ratios used to measure the profitability of companies. Within the scope of this study, return on equity, which is one of the ratios measuring profitability, was used. The return on equity, which shows the financial performance of the business, is calculated by dividing the net profit after tax to equity (Van Horne \& Wachowicz, 1995, s. 142).

Many previous studies on airline performance have focused mainly on operational activities. Financial performance that can affect an airline's survival can often be overlooked. Indeed, the financial performance of an airline company in an increasingly competitive environment must be carefully observed (Wang, 2008, s. 1837). The presence of a highly competitive environment in the airline industry has had a highly positive impact on consumers, business activities and the tourism industry. To cope with this increasingly competitive environment, airlines are desperately focused on improving their operational performance ( $\mathrm{Yu}$, Chen \& Chiang, 2017, s. 197).

The ability of airlines to survive in tough competitive conditions is possible by accurately determining and evaluating their performance. Assessment of financial performance provides benefits to business managers in terms of detecting inadequacies, determining factors affecting performance, and achieving future goals (Macit \& Göçer, 2020, s. 904).

Despite the important role of full service airlines supporting trade and tourism through their mobility capabilities (Gunn, 2002, s. 33; Middleton \& Clarke, 2001, s. 15), the increase in fleet size and flight frequency leads to fierce competition (Austria, 2000, s. 17). In addition, full-service airlines are struggling with fierce competition on mutual routes resulting from low cost airlines entering the market (Citrinot \& Bailey, 2006, s. 1). There are also studies examined by researchers and industry professionals that focus on evaluating the competitiveness of airline businesses (Delbari, Ng, Aziz, \& Ho, 2016, s. 23). Competitiveness for full service airlines has been examined with financial indicators such as profitability (Jenatabadi \& Ismail, 2014, s. 25; Parast \& Fini, 2010, s. 458).

Incorrect decisions made in terms of financial and operational management can result in higher operational costs and, if the resulting financial difficulties cannot be dealt with, they can lead to a bankruptcy statement or the shutdown of the airline. In airlines, it is vital that managers are able to determine and evaluate the financial and operational performance of the company, and as a result, make the necessary improvements (Pineda, Liou, Hsu, \& Chuang, 2018, s. 103).

Airlines struggle to improve their operational performance and therefore increase their profitability (Parast \& Fini, 2010, s. 458). Therefore the question is, what are the operational performance indicators of flag-carrier airlines that maximize their return on equity?

In this study, the effect of RPK, load factor and number of passengers, which are among the indicators of the operational performance of airlines, on the return on equity will be examined. In the study, the direction and degree of the relationship between independent variables and equity profitability will be revealed specifically for Turkish Airlines. Porter (1990) stated that businesses should compete in international markets, not with industries or nations. Does Turkish Airlines hold the title of 'the airline that flies to the most countries in the world' in recent years (Curran, 2019) positively affect profitability through RPK?

\section{Literature Review}

There have been many studies examining various aspects of operational performance in airlines and their effects on financial and market performance. (Scheraga, 2004, s. 383; Bhadra, 
2009, s. 227; Merkert \& Hensher, 2011, s. 686; Merkert \& Pearson, 2015, s. 261; Barros \& Couto, 2013, s. 11). These studies differ in terms of the type, size and quality of the data sets and the econometric methods used by the researchers.

Day1 and Sezgin Alp (2020) evaluated the efficiency of fuel cost of airline companies and the factors affecting financial performance. In the study, Data Envelopment Analysis was carried out in order to evaluate the efficiency of 15 airline companies operating in the AsiaPacific continent, and the financial ratios that affect the efficiency levels of the companies were determined by the decision tree method. In the study, it was determined that the most important variable in order of importance among the variables was the fixed assets/constant capital ratio. Since airlines spend large amounts of capital, the ratio is important in determining the efficient use of fixed assets.

Day1 and Ulusoy (2020) examined the financial performance of airline companies using various ratios. As financial performance indicators, Accounts Receivables Turnover Rate, Average Collection Period of Receivables, Inventory Turnover Average Inventory Turnover Period, Asset Turnover, Net Profit Ratio, Return on Assets Ratio and Return on Equity were used. The results of the study using the Minimum Spanning Tree method show that airline companies have increased their financial performance and Turkish Airlines has grown in terms of profitability, total assets and sales revenues every year.

Dayı (2019) examined the relationship between operating leverage and sales revenues by using panel data analysis method using the data of 20 airline companies, including at least one company from every continent of the world. According to the results of the analysis, a positive correlation was determined between the degree of operating leverage and sales revenues. As the number of revenue passengers increases, more sales revenue is generated by the leverage effect. The increase in the load factor also positively affected the performance of the companies. There is a positive relationship between financial leasing expenses and sales revenues. A positive relationship was also found between sales revenues and return on assets.

Pineda, Liou, Hsu, and Chuang (2018) proposed an integrated soft computer model to set various indicators for improvement of airline performance. The model developed in the study determined the interrelationship between critical factors and the degree of these factors in order to identify the strengths and weaknesses of airlines in operational and financial performance and determine the necessary improvement aspects. It has been determined that operational performance indicators have an effect on financial performance.

Alan and Lapre (2017) examined the impact of operational performance on future financial problems in airlines. Four different operational performance areas were examined in the study. According to the findings of the study, it was determined that airlines with high operational complexity and low capacity utilization may experience more financial problems in the future. On the other hand, there was no correlation between average service quality and future financial problems.

Nasir, Ahmed, and Barkat (2017) empirically examined the effect of operational performance on financial performance in Malaysia Airlines. The findings suggested that operational performance of Malaysia Airlines has no effect on profitability. On the other hand, employee productivity and capacity utilization were found to have a high degree of positive effect on incomes.

Mantin and Wang (2012) empirically investigated the effects of operations strategy, productivity, and service measures on profitability. In the study, it was determined that all three types of measures have a positive effect on profitability. When the stage length increases, a negative effect is observed on profitability. It has been determined that both loading factors and aircraft utilization have a high degree of positive impact on profitability. 
Parast and Fini (2010) examined the effect of productivity and quality on profitability. Findings show that there is a positive correlation between labor productivity and profitability. It has been observed that on-time performance has no effect on profitability.

Tsikriktsis (2007) examined the impact of operational performance on profitability. The analysis shows that operational performance has a positive impact on profitability in terms of efficiency and quality. The study showed a link between "Focused" airlines and late arrivals and profitability, while full-service airlines did not. Additionally, capacity utilization has a higher rate of impact on profitability for full service airlines than focused airlines. Finally, the study suggested that focused airlines performed better than other airlines operating in the US domestic airline industry in terms of profitability.

Behn and Riley (1999) examined the effect of non-financial operational performance indicators on financial performance. On-time performance, mishandled baggage, overbooked flights and in-flight service have been found to be significantly associated with customer satisfaction, and customer satisfaction has been found to have a positive impact on the load factor, market share and operating revenues of the available tonne kilometres.

One of the main reasons for this study is that there has not been an empirical study examining the relationship between operational performance indicators and profitability in the Turkish airline industry.

\section{Data and Variables}

In the literature, it is stated that load factor, aircraft capacity, aircraft size, network size, hubs, service quality, seasonality, available seat kilometers, revenue passenger kilometers are generally used as operational performance indicators (Francis \& Humphreys, 2005, s. 207; Coelli, Perelman \& Romano, 1999, s. 251; Ahn, Good \& Sickles, 1997, s.20; Good, Röller \& Sickles, 1995, s. 508; Baltagi, Griffin \& Rich, 1995, s. 245; Cornwell, Schmidt \& Sickles, 1990, s. 185; Schmidt \& Sickles, 1984, s. 367). To explain the operational indicators used in the study, the revenue passenger kilometer (RPK) is the value obtained by multiplying the paid passenger carried at each flight stage and the kilometers flown. It is the total number of kilometers traveled by all paid passengers (Oum \& You, 1998, s. 407; Scheraga, 2004, s. 383; Bhadra, 2009, s. 227). The load factor (LF) is a ratio that increases in direct proportion to the number of passengers. Increasing the load factor (LF) allows fixed costs to be distributed to more passengers per flight, thus reducing the cost per passenger on the flight (Zhang et al., 2014, s. $8)$.

While this study contributes to the understanding of operational performance indicators that affect return on equity, only the Turkish flag carrier, Turkish Airlines, is included in the dataset used in the study. Since sufficient time series data sets are only available at Turkish Airlines.

This study requires operational and financial data. The data set were obtained from the Annual Reports issued by Turkish Airlines, includes 40 observations on a quarterly basis between 2010 and 2019. While return on equity (ROE) is determined as the dependent variable in the study, passenger load factor (LF), number of revenue passenger (PAX) and revenue passenger kilometers (RPK), which are among the operational performance indicators commonly used in the literature, constitute the independent variables.

\section{Empirical Analysis}

\subsection{Descriptives, Methodology, Empirical Results and Discussion}

Long and short term relationships between variables can be analyzed using different methods. Cointegration analysis is used to reveal the long-term relationship between variables. Engle Granger (1987) and Johansen (1988) developed a classical cointegration method, and analyzes can be made in these methods if the variables are stationary at the same level. This is 
an important constraint for cointegration tests, and the ARDL model was used in this study because the variables in the model are stationary at different levels. ARDL (Autoregressive Distibuted Lag) boundary test approach developed by Pesaran and Shin (1995) and Pesaran, Shin and Smith (2001) overcomes the problem of not applying the cointegration method to series with different degrees of cointegration. The possibility of including the error correction model of the ARDL approach enables the model to obtain more reliable results.

ARDL model is defined as below in order to analysis of impacts of passenger load factor (LF), number of revenue passenger (PAX) and revenue passenger kilometers (RPK) on return on equity (ROE).

$$
y_{t}=\alpha+\sum_{i=1}^{p} \gamma_{i} y_{t-i}+\sum_{j=1}^{k} \sum_{i=0}^{q_{j}} X_{j, t-i}{ }^{\prime} \beta_{j, i}+\epsilon_{t}
$$

ARDL $\left(p, q_{1}, \ldots, q_{k}\right)$, where $\mathrm{p}$ is the number of lags of the dependent variable, $\mathrm{q}_{1}$ is the number of lags of the first explanatory variable, and $\mathrm{q}_{\mathrm{k}}$ is the number of lags of the $k$-th explanatory variable.

In the application of the model, the stationarities of the dependent and independent variables were examined with the Augmented Dickey-Fuller test (ADF) and Phillips-Perron test (PP), and as seen in Table 1, the variables were determined to be stationary at different levels. This situation is decisive in model selection and makes it possible to apply ARDL in examining the relationship between variables.

Table 1. Unit root tests

\begin{tabular}{lccccc}
\hline \multirow{2}{*}{ Variables } & \multicolumn{2}{c}{ ADF } & \multicolumn{2}{c}{ PP } \\
\cline { 2 - 6 } & & Intercept & Intercept\&Trend & Intercept & Intercept\&Trend \\
\hline \multirow{2}{*}{ ROE } & $\mathrm{I}(0)$ & -1.5996 & -1.5475 & -2.3822 & -2.2775 \\
\cline { 2 - 6 } & $\mathrm{I}(1)$ & $-4.1458^{*}$ & $-4.0491^{*}$ & $-6.1366^{*}$ & $-6.3017^{*}$ \\
\hline \multirow{2}{*}{$\mathrm{LF}$} & $\mathrm{I}(0)$ & $-4.1257^{*}$ & $-4.4214^{*}$ & -1.8492 & -2.3478 \\
\cline { 2 - 6 } & $\mathrm{I}(1)$ & & & $-5.5931^{*}$ & $-5.4796^{*}$ \\
\hline \multirow{2}{*}{$\mathrm{PAX}$} & $\mathrm{I}(0)$ & -2.2557 & 0.3638 & $-5.1137^{*}$ & $-10.509^{*}$ \\
\cline { 2 - 6 } & $\mathrm{I}(1)$ & -0.7826 & $-3.6582^{*}$ & & -2.3478 \\
\hline \multirow{2}{*}{ RPK } & $\mathrm{I}(0)$ & $-4.1257^{*}$ & $-4.4214^{*}$ & -1.8492 & $-5.4796^{*}$ \\
\cline { 2 - 6 } & $\mathrm{I}(1)$ & & & $-5.5931^{*}$ &
\end{tabular}

* Statistically significant at the 5\%

The smallest critical value of Akaike Information Criteria was determined as lag length in the model.

The cointegration relationship between variables in the context of the chosen ARDL (2.1.4.3) model is revealed by the boundary test. Boundary test results of the relevant model are given in Table 2. 
Figure 1. Akaike information criteria

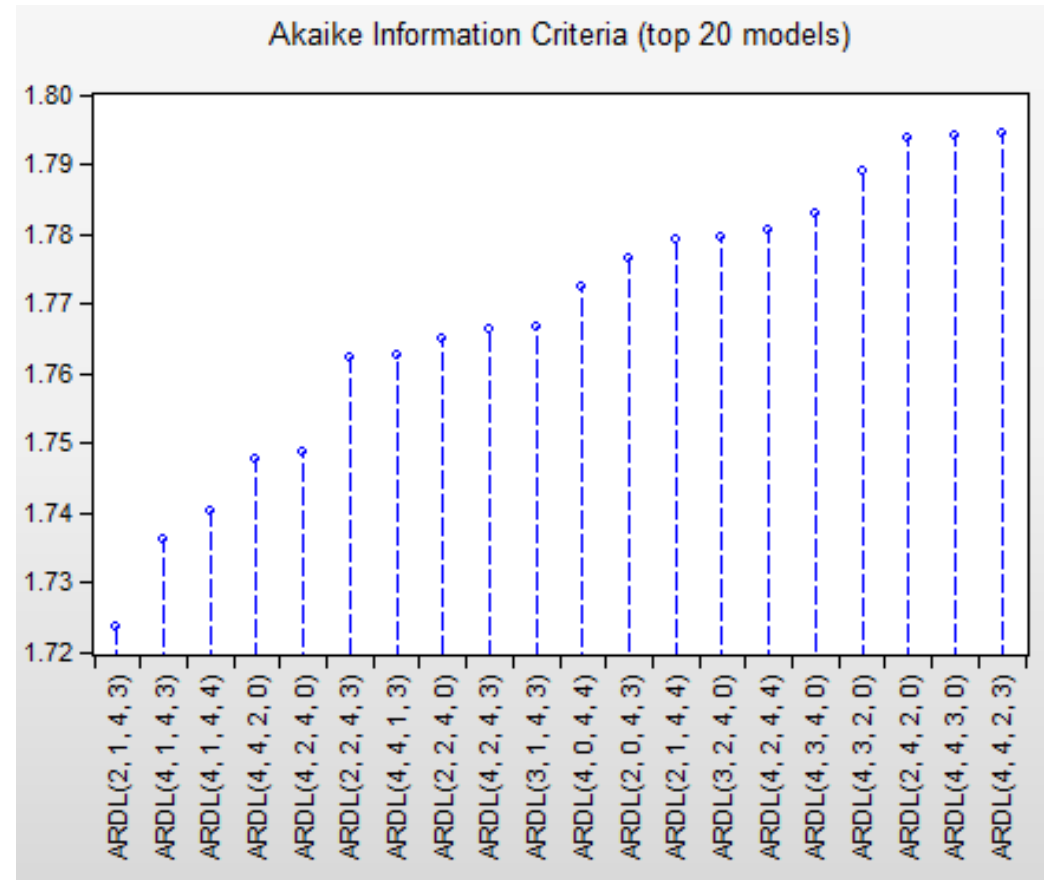

As a result of the boundary test, the F statistic value (4.839818) was calculated at 5\% significance level, greater than the upper critical value, and it is understood that there is a longterm cointegration relationship between the variables.

Table 2. ARDL bounds test

\begin{tabular}{ccc}
\hline Test Statistic & Value & $\mathrm{k}$ \\
\hline F-statistic & 4.839818 & 3 \\
\hline Critical Value Bounds & & \\
\hline Significance & & I1 Bound \\
\hline $10 \%$ & I0 Bound & 3.77 \\
\hline $5 \%$ & 2.72 & 4.35 \\
\hline $2.5 \%$ & 3.23 & 4.89 \\
\hline $1 \%$ & 3.69 & 5.61 \\
\hline
\end{tabular}

The coefficients and directions of the variables were estimated in the long-term relationship determined between the variables. According to the long-term model results in Table 3, revenue passenger kilometer has a statistically significant but negative effect on the return on equity. A low rate of positive correlation has been found between the number of revenue passengers and the return on equity. Passenger load factor has been found to positively affect the return on equity.

Table 3. Long run coefficients of cointegration

\begin{tabular}{ccccc}
\hline Variable & Coefficient & Std. Error & t-Statistic & Prob. \\
\hline RPK & -0.000000 & 0.000000 & -2.490950 & 0.0208 \\
\hline PAX & 0.000001 & 0.000000 & 2.368382 & 0.0271 \\
\hline LF & 23.945992 & 5.765858 & 4.153067 & 0.0004 \\
\hline C & -18.384227 & 4.001145 & -4.594742 & 0.0001 \\
\hline
\end{tabular}

The error correction model, which is established in terms of containing information about the short-term balance in the model, shows the situation where the imbalances that occur 
in the short term are eliminated in the long term. The results regarding the error correction model are given in Table 4.

Table 4. Error correction model

\begin{tabular}{ccccc}
\hline Variable & Coefficient & Std. Error & t-Statistic & Prob. \\
\hline $\mathrm{D}($ ROE(-1)) & 0.537847 & 0.174817 & 3.076635 & 0.0055 \\
\hline $\mathrm{D}(\mathrm{RPK})$ & -0.000000 & 0.000000 & -1.148529 & 0.2631 \\
\hline $\mathrm{D}(\mathrm{PAX})$ & 0.000000 & 0.000000 & 0.620955 & 0.5410 \\
\hline $\mathrm{D}(\mathrm{PAX}(-1))$ & 0.000000 & 0.000000 & 0.945214 & 0.3548 \\
\hline $\mathrm{D}(\mathrm{PAX}(-2))$ & -0.000000 & 0.000000 & -1.159168 & 0.2588 \\
\hline $\mathrm{D}(\mathrm{PAX}(-3))$ & -0.000000 & 0.000000 & -2.357685 & 0.0277 \\
\hline $\mathrm{D}(\mathrm{LF})$ & 21.141768 & 8.958211 & 2.360044 & 0.0276 \\
\hline $\mathrm{D}(\mathrm{LF}(-1))$ & -28.010437 & 8.934282 & -3.135164 & 0.0048 \\
\hline $\mathrm{D}(\mathrm{LF}(-2))$ & 11.663232 & 6.624981 & 1.760493 & 0.0922 \\
\hline CointEq(-1) & -0.811453 & 0.189423 & -4.283821 & 0.0003 \\
\hline
\end{tabular}

While evaluating the error correction model, the significance and direction of the error correction term should be taken into account. If the error correction term is statistically significant and negative, the error correction model works and short-term imbalances are eliminated in the long-term.

The error correction coefficient of the error correction model established within the scope of the study is statistically significant and negative. In this case, the deviation from balance that occurs in the short term in the model is eliminated in the long term.

Whether the ARDL model includes structural break or not is tested with the CUSUM and CUSUMQ structural break tests developed by Brown, Durbin and Evans (1975). The CUSUM Test is based on cumulative error terms in relation to the (n) observation set and is drawn between two critical lines showing 5\% significance. If the curve obtained from the CUSUM test statistics shown regarding the error terms is between the critical limit showing 5\% significance, the estimated coefficients are considered to be stable in the long run. The same process CUSUMQ is determined based on the squares of the cumulative error terms and the significance test is evaluated. CUSUM and CUSUMQ test results regarding the model are given in Figure 2 and Figure 3.

Figure 2. CUSUM model stability tests

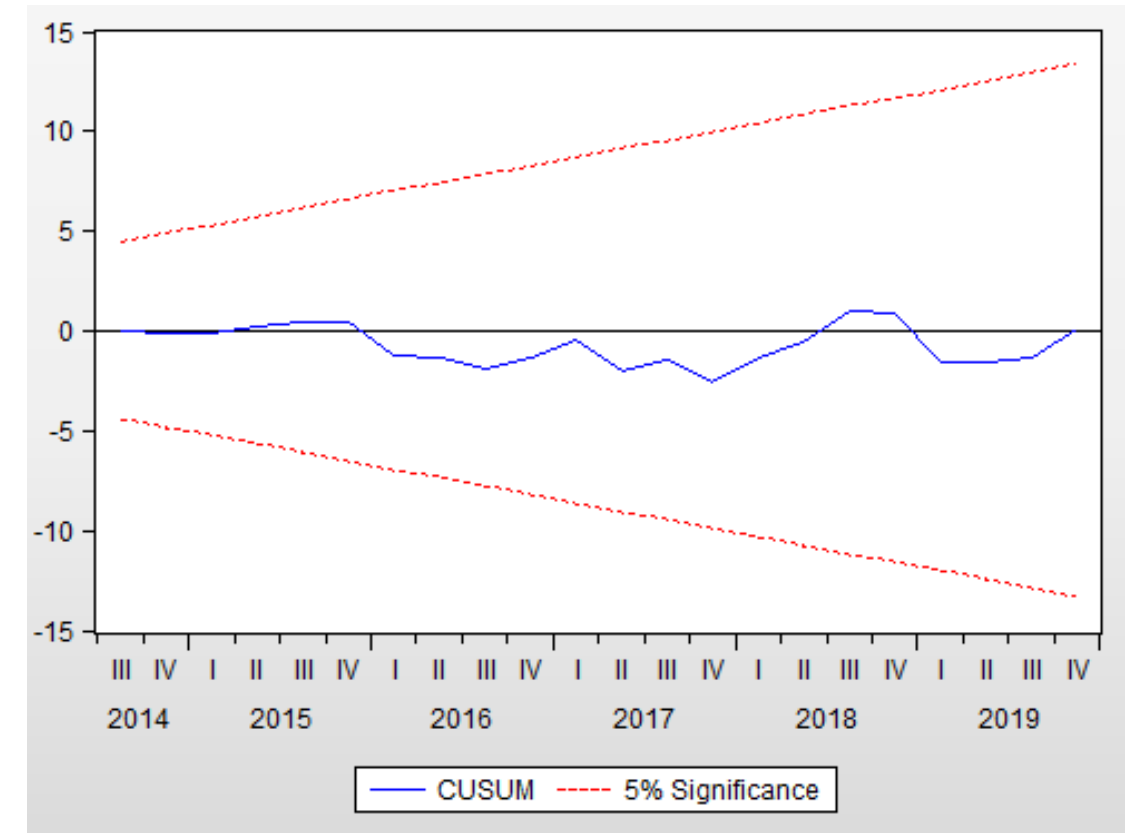


Figure 3. CUSUMQ Model Stability Test

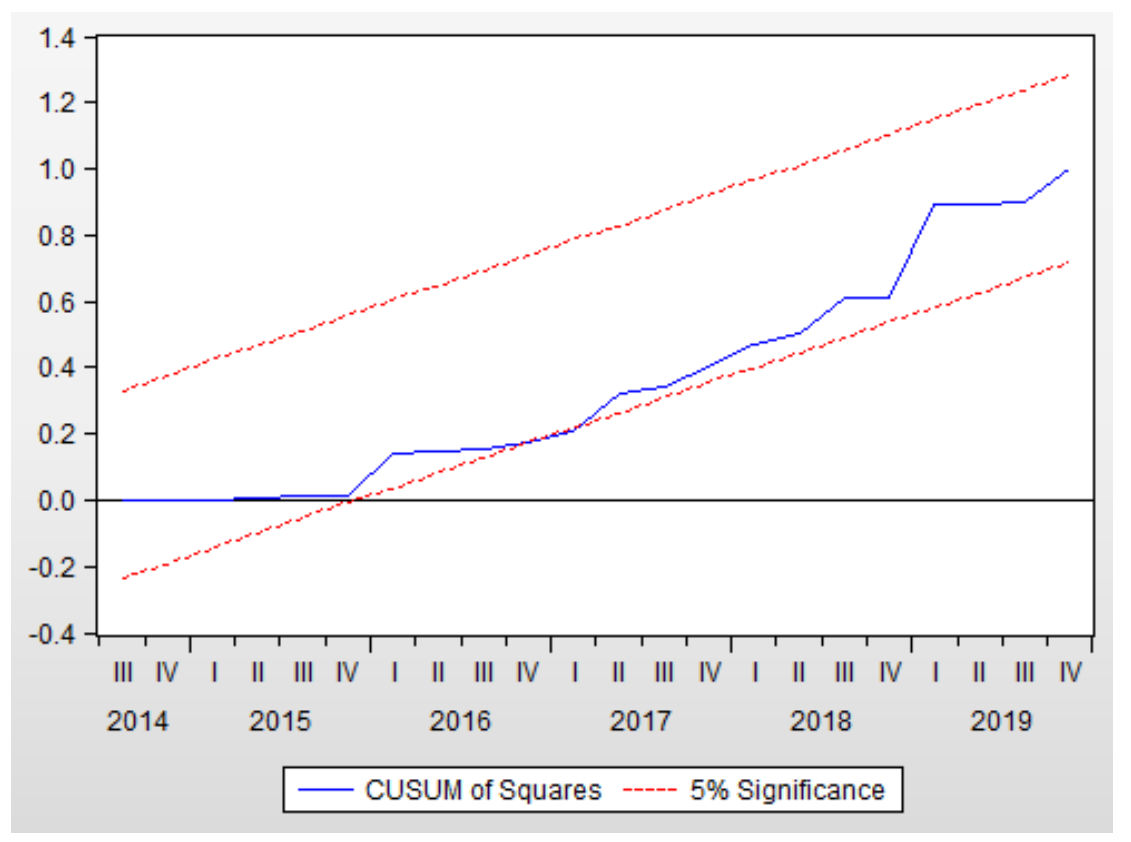

Since the curve obtained from the CUSUM and CUSUMQ test statistics estimated in Figure 2 and Figure 3 is between the critical limit showing 5\% significance, it is seen that the estimated coefficients are stable in the long term and there is no structural break.

As stated in the literature part of the study, Day1 (2019) examined that as the number of revenue passengers increases, more sales revenue is obtained with the leverage effect and the increase in the load factor positively affects the performance of the companies. Mantin and Wang (2012) found that both the loading factor and aircraft utilization have a highly positive effect on profitability. Tsikriktsis (2007) revealed that operational performance has a positive effect on profitability in terms of efficiency and quality.

The findings obtained from the analysis of the study confirm the results in the literature. According to the long-term model results, a positive correlation has been found between the number of revenue passengers and the return on equity. Additionally, passenger load factor has been found to positively affect the return on equity.

\section{Conclusion}

It is imperative that airlines carefully manage their financial performance in high competitive environment, and in this context, their survival is only possible by accurately determining and evaluating their operational and financial performance. Therefore, for fullservice airlines competing with low cost airlines on mutual routes, it is inevitable to focus on financial performance and the operational indicators that affect it.

In this study, it is aimed to examine the effect of RPK, load factor and number of passengers on the return on equity, which are the indicators of the operational performance of the airlines, and in this context, the direction and degree of the relationship between the return on equity has been revealed for Turkish Airlines.

The study suggests that the passenger load factor has a significant effect on the return on equity. It is seen that 1 unit of increase in passenger load factor causes 23.9 units of increase in the return on equity. Based on this, it is concluded that in cases where the increase in the number of revenue passenger is not supported by the passenger load factor, in other words, because of the flights where the breakeven point is not exceeded in terms of cost, revenue 
passenger kilometer and the number of revenue passenger cannot affect the return on equity positively.

It has been revealed that the revenue passenger kilometer has a low negative effect on the return on equity, and number of revenue passenger has a low positive effect on the return on equity. Empirical results show that when the increase in the number of revenue passenger is not supported by passenger load factor, in other words, because of the flights where the breakeven point is not exceeded in terms of cost, it is evaluated that RPK and the number of revenue passenger do not affect the return on equity positively.

In the new normal post-COVID-19 era, in an increasingly competitive environment, Turkish Airlines should realize of the illusion of flying to the most countries and focus on passenger load factor.

While this study contributes to the understanding of operational performance indicators that affect return on equity, it has some limitations. Considering the data set used in the study, the results are specific to only Turkish Airlines. Future research could examine the relationship between profitability and different operational performance indicators for specific airlines.

\section{References}

Ahn, S. C., Good, D. \& Sickles, R. C. (1997). A dynamic frontier approach to assessing the relative efficiency of Asian and North American airline firms. Presented at the Taipei International Conference on Efficiency and Productivity Growth.

Alan, Y., \& Lapré, M. A. (2017). Investigating operational predictors of future financial distress in the US airline industry. Production and Operations Management, 27(4), 734-755. doi: 10.1111/poms. 12829

Apak, S. ve Demirel E. (2010). Finansal Yönetim, İstanbul: Papatya Yayınevi.

Austria, M. (2000). The state of competition and market structure of the Philippine air transport industry. Philipp. Inst. Dev. Stud. Discussion Paper No. 2000-12.

Baltagi, B. H., Griffin, J. M. \& Rich, D. P. (1995). Airline deregulation: the cost pieces of the puzzle. International Economic Review, Vol. 36, 245-259. doi: 10.2307/2527435

Barros, C. P., \& Couto, E. (2013). Productivity analysis of European airlines, 2000-2011. J. Air Transp. Manag. 31, 11-13. doi: 10.1016/j.jairtraman.2012.10.006

Behn, B. K., \& Riley Jr. R. A. (1999). Using nonfinancial information to predict financial performance: The case of the US airline industry. Journal of Accounting, Auditing \& Finance, 14(1), 29-56. doi: 10.1177/0148558X9901400102

Bhadra, D. (2009). Race to the bottom or swimming upstream: performance analysis of US airlines. Journal of Air Transport Management 15.5: 227-235. doi: 10.1016/j.jairtraman.2008.09.014

Brown, R. L., Durbin, J., \& Evans, J. M. (1975). Techniques for testing the constancy of regression relationships over time. Journal of the Royal Statistical Society: Series B (Methodological), 37(2), 149-163. doi: 10.1111/j.2517-6161.1975.tb01532.x

Citrinot, L., \& Bailey, M. (2006). Low-cost airlines-international. Travel \& Tour. Analyst 19, 1 63.

Coelli, T., Perelman, S., \& Romano, E. (1999). Accounting for environmental influences in stochastic frontier models: with application to international airlines. Journal of Productivity Analysis, Vol. 11, 251-273. doi: 10.1023/A:1007794121363 
Cornwell, C., Schmidt, P., \& Sickles, R. C. (1990). Production frontiers with cross-sectional and time-series variation in efficiency levels. Journal of Econometrics, Vol. 46 No: 1/2, 185-200. doi: 10.1016/0304-4076(90)90054-W

Curran, A. (2019). Turkish Airlines Now Fly To An Incredible 125 Countries, https://simpleflying.com/turkish-airlines-125-countries/ (Access date: 21.12.2020).

Dayı, F., \& Sezgin Alp, Ö. (2020). Efficiency Estimating in Airline Companies: An Application on Asia-Pacific Companies. Journal of Accounting \& Finance, (86), 185-204. doi: 10.25095/mufad.710361

Dayı, F., \& Ulusoy, T. (2020). The Effect of Operating Ratios on Firm Value: An Application in European Airlines. International Journal of Eurasia Social Sciences, 11(40), 493-505. doi: $10.7827 /$ TurkishStudies. 14348

Dayı, F. (2019). Faaliyet Kaldıraç Derecesinin Satış Gelirleri Üzerindeki Etkisi: Havayolu Şirketlerinde Bir Uygulama. Afyon Kocatepe Üniversitesi Sosyal Bilimler Dergisi, 21(3), 923-941. doi: 10.32709/akusosbil.499374

Delbari, S. A., Ng, S. I., Aziz, Y. A., \& Ho, J. A. (2016). An investigation of key competitiveness indicators and drivers of full-service airlines using Delphi and AHP techniques. Journal of Air Transport Management, 52, 23-34. doi: 10.1016/j.jairtraman.2015.12.004

Engle R. F., \& Granger C. W. J. (1987). Co-integration and error correction: representation, estimation and testing. Econometrica, 55, 251-276. doi: 10.2307/1913236

Francis, G., Humphreys, I., \& Fry, J. (2005). The nature and prevalence of the use of performance measurement techniques by airlines. Journal of Air Transport Management, 11(4), 207-217. doi: 10.1016/j.jairtraman.2004.10.003

Good, D., Röller, L. H., \& Sickles, R. C. (1995). Airline efficiency differences between Europe and the US: implications for the pace of EC integration and domestic regulation. European Journal of Operational Research, Vol. 80, 508-518. doi: 10.1016/0377-2217(94)00134-X

Gunn, C. A. (2002). Tourism Planning. Taylor and Francis, New York.

Horne V. J., \& Wachowicz, J. M. (1995). Fundamentals of Financial Management. New jersey: Prentice Hall International Editions.

İskenderoğlu Ö., Karadeniz E., ve Atioğlu E. (2012). Türk bankacılık sektöründe büyüme, büyüklük ve sermaye yapısı kararlarının karlılığa etkisinin analizi. Eskişehir Osmangazi Üniversitesi Iktisadi ve İdari Bilimler Dergisi 7.1, 291-311.

Jenatabadi, H. S., \& Ismail, N. A. (2014). Application of structural equation modelling for estimating airline performance. J. Air Transp. Manag. 40, 25-33. doi: 10.1016/j.jairtraman.2014.05.005

Johansen, S. (1988). Statistical analysis of cointegration vectors. Journal of Economic Dynamics and Control, 12, 231-254. doi: 10.1016/0165-1889(88)90041-3

Macit, D., ve Göçer, S.G. (2020). Havayolu İşletmelerinin Finansal Performanslarının Ölçülmesi: Pegasus Hava Taşımacılığı AŞ ve THY AO Örneği. ODÜ Sosyal Bilimler Araştırmaları Dergisi, 10(3), 904-918. doi: 10.48146/odusobiad.689222

Mantin, B., \& Wang, J. H. E. (2012). Determinants of profitability and recovery from systemwide shocks: The case of the airline industry. Journal of Airline and Airport Management, 2(1), 1-21. doi: 10.3926/jairm.2 
Merkert R., \& Hensher, D. A. (2011). The impact of strategic management and fleet planning on airline efficiency - a random effects Tobit model based on DEA efficiency scores. Transp. Res. Part A 45, 686-695. doi: 10.1016/j.tra.2011.04.015

Merkert, R., \& Pearson, J. (2015). A non-parametric efficiency measure incorporating perceived airline service levels and profitability. J. Transp. Econ. Policy (JTEP) 49 (2), 261-275.

Middleton, V. T. C., \& Clarke, J. (2001). Marketing in Travel and Tourism. Butterworth and Heinemann, Oxford.

Nasir A. M., Ahmed A., \& Barkat, W. (2017). Operational performance and financial performance of Malaysia Airlines. Paradigms, 11(1), 34-40

Oum, T. H., \& You, C. (1998). Cost competitiveness of major airlines: An international comparison. Transport Research Part A 32, 407-422. doi: 10.1016/S0965-8564(98)00007-X

Parast, M. M., \& Fini, E. E. H. (2010). The effect of productivity and quality on profitability in US airline industry: an empirical investigation. Managing Service Quality: An International Journal. Vol. Issue 5, 458-474. doi: 10.1108/09604521011073740

Pesaran, H., \& Shin, Y. (1995). An autoregressive distributed lag modelling approach to cointegration analysis. In S. Strom, A. Holly \& A. Diamond (Eds.). Centennial Volume of Ranger Frisch. Cambridge University Press.

Pesaran H., Shin Y., \& Smith, R. J. (2001). Bound testing approaches to the analysis of long run relationship. Journal of Applied Econometrics, 16(3), 289-326. doi: 10.1002/jae.616

Pineda, P. J. G., Liou, J. J., Hsu, C. C., \& Chuang, Y. C. (2018). An integrated MCDM model for improving airline operational and financial performance. Journal of Air Transport Management, 68, 103-117. doi: 10.1016/j.jairtraman.2017.06.003

Porter, M. E. (1990). The competitive advantage of nations. The Free Press, New York.

Schefczyk, M. (1993). Operational performance of airlines: an extension of traditional measurement paradigms. Strategic Management Journal, Vol. 14 No. 4, 301-317. doi: $10.1002 / \mathrm{smj} .4250140406$

Scheraga, C. A. (2004). Operational efficiency versus financial mobility in the global airline industry: a data envelopment and Tobit analysis. Transp. Res. Part A 38, 383-404. doi: 10.1016/j.tra.2003.12.003

Schmidt, P., \& Sickles, R. (1984). Production frontiers and panel data. Journal of Business and Economic Statistics, Vol. 2 No. 4, 367-374. doi: 10.1080/07350015.1984.10509410

THY AO. (2020). THY Annual Reports, https://investor.turkishairlines.com/tr/mali-veoperasyonel-veriler/faaliyet-raporlari (Access date: 21.12.2020).

Tsikriktsis, N. (2007). The effect of operational performance and focus on profitability: a longitudinal study of the US airline industry. Manufacturing and Service Operations Management, Vol. 9 No. 4, 506-517. doi: 10.1287/msom.1060.0133

Türkiş, İ. (2001). Kar Kavramına Kuramsal Yaklaşım. Vergi Sorunları Dergisi, (158).

Wang, Y. J. (2008). Applying FMCDM to evaluate financial performance of domestic airlines in Taiwan. Expert Systems with Applications, 34(3), 1837-1845. doi: 10.1016/j.eswa.2007.02.029

Yu, M. M., Chen, L. H., \& Chiang, H. (2017). The effects of alliances and size on airlines' dynamic operational performance. Transportation Research Part A: Policy and Practice, 106, 197-214. doi: 10.1016/j.tra.2017.09.015 
Zhang, Q., Yang, H., Wang, Q., \& Zhang, A. (2014). Market power and its determinants in the Chinese airline industry. Transportation Research Part A: Policy and Practice, 64, 1-13. doi: 10.1016/j.tra.2014.03.003

\section{ETİK ve BİLIMSEL İLKELER SORUMLULUK BEYANI}

$\mathrm{Bu}$ çalışmanın tüm hazırlanma süreçlerinde etik kurallara ve bilimsel atıf gösterme ilkelerine riayet edildiğini yazar(lar) beyan eder. Aksi bir durumun tespiti halinde Afyon Kocatepe Üniversitesi Sosyal Bilimler Dergisi'nin hiçbir sorumluluğu olmayıp, tüm sorumluluk makale yazarlarına aittir. 